Bulletin UASVM Food Science and Technology 70(2)/2013, 143-144

ISSN-L 2344-2344; Print ISSN 2344-2344; Electronic ISSN 2344-5300

\title{
Research on the Sensorial Quality and Economic Efficiency in Obtaining of a certain Raw Meat Product - Mici Paste
}

\author{
Claudiu-Dan SĂLĂGEAN ${ }^{1)}$, Dorin ŢIBULCĂ ${ }^{1)}$, Radu MARIN ${ }^{2)}$ \\ ${ }^{1)}$ University of Agricultural Sciences and Veterinary Medicine, Faculty of Food Science and Technology, \\ 3-5 Mănăştur Street, 400372 Cluj-Napoca, Romania, salageancd@yahoo.com,dorin.tibulca@yahoo.com \\ ${ }^{2)}$ SC Vitalim Ingrediente SRL, Codrului 42-44, Măgurele, Ilfov, Romania, raduvitalim@yahoo.com
}

\begin{abstract}
Research aimed the sensorial quality connected with the economic efficiency to obtain a certain raw meat product (Mici paste) in 4 experimental variants. The $2^{\text {nd }}$ and $4^{\text {th }}$ variants reveals higher functional, technical and economic advantages and also the customer satisfaction compared with $1^{\text {st }}$ and $3^{\text {rd }}$ variants.
\end{abstract}

Keywords: Mici paste, sensorial analysis, economic efficiency, specific consumption, technological losses, experimental variants, sample

Introduction: The use of soy protein supplements in the processing of the meat products has spread on the national and international scale due to their technique-functional advantages (fat emulsification and emulsion stability, the increase of hydrating and water retention capacity, moisture content, a better structure and texture of the finished product), nutritional advantages (the increase of nutritional value through the rich essential amino-acid content of these proteins) and economical advantages (the decrease of the specific consumption in the processing of the meat products). Great results are obtained by using vegetable protein supplements with mixes of additives; in addition, ensure increased efficiency of production and the price of the product significantly reduced, which reflects positively on the consumer (Banu et al., 1997; Sălăgean, 2006).

Aims and objectives: Research aimed the quality connected with the economic efficiency to obtain a certain raw meat product (Mici paste) in 4 experimental variants.

Materials and methods: In this respect, the following technological variants have been used:

1 and 3 variants, with animal raw materials (meat + bacon) and mix of natural spices fine grinding variant (1) and coarse grinding variant (3) - chopping at the volf through the sieve of 3-4 mm; 2 and 4 variants, with animal raw materials (meat + bacon) + vegetable protein supplements (textured soy protein) + binder (protein + fiber) + additive mix - fine grinding variant (2) and coarse grinding variant (4) - chopping at the volf through the sieve of 3 - $4 \mathrm{~mm}$.

Moreover sensorial analyzes were performed on appearance (exterior and section), color, smell, texture and taste of the finished product (after roasting).

Results and Discussion: The results of the sensorial analysis of the Mici paste samples obtained in the four experimental variants are shown in Tab. 1.

The results have highlighted that, in terms of sensorial, sample 1 obtained the highest score (on a scale of 1-poor to 5-very good quality) (average 21.83), followed by sample 3 (average 19.22), the very small difference in the case of sample 2 (average 19.19) and finally, sample 4 (average 18.75). 
Tab. 1

The results of the sensorial analysis of the Mici paste samples obtained in the four experimental variants

\begin{tabular}{|c|c|c|c|c|c|}
\hline No. & Indicator & Sample 1 & Sample 2 & Sample 3 & Sample 4 \\
\hline 1. & Appearance & 4.33 & 3.94 & 3.94 & 3.67 \\
\hline 2. & Color & 4.39 & 4.28 & 4.17 & 4.17 \\
\hline 3. & Smell & 4.67 & 3.81 & 3.94 & 4.08 \\
\hline 4. & Texture & 4.33 & 3.5 & 3.5 & 3.44 \\
\hline 5. & Taste & 4.11 & 3.67 & 3.67 & 3.39 \\
\hline & TOTAL (average) & 21.83 & 19.19 & 19.22 & 18.75 \\
\hline
\end{tabular}

Values: $1 \ldots 5$ ( 1 - poor quality; 2 - satisfactory quality; 3 - pretty good quality; 4 - good quality; 5 - very good quality)

It was noted that sample 1 obtained the highest score (average) of all analyzed sensorial indicators: appearance (4.33), color (4.39), smell (4.67), texture (4.33) and taste (4.11) being favorite by all volunteer subjects who participated at the analysis. The same thing was found in sensory analysis of Mici paste in fresh/chilled condition: $65 \%$ of subjects preferred variant 1 followed by variant $3(19.2 \%)$, variant $2(11.5 \%)$ and finally, variant $4(3.8 \%)$.

In terms of economic the highest efficiency was found in 2 (specific consumption 0.73 ) and 4 (specific consumption 0.77) variants compared to 1 (specific consumption 0.80 ) and 3 (specific consumption 0.82) variants, which translates into a reduction in the cost of products manufactured in the variants 2 and 4 (with protein supplements and additive mix) by about 25$20 \%$ (with importance for the manufacturer). Also, thermal processing (roasting) revealed the highest weight loss (drying) in $3(18.75 \%)$ and $1(12.50 \%)$ variants compared to $4(12.33 \%)$ and $2(10 \%)$ variants in which case the vegetable protein supplements contributed to increased water retention capacity, and the processing way of the raw materials - their mechanical grinding (in this case) was another important factor that influenced the level of these technological losses that have a negative impact on the consumer.

Conclusion: In conclusion, the 2 and 4 variants revealed higher functional, technical and economic advantages compared with 1 and 3 variants and also the customer satisfaction.

Following this research, at the observed qualitative differences we can define a range of acceptability, such as: 3.5 to 4.5 notes are good and very good quality products, so that may be preferred commercial and financial advantages (about 20\%), lower losses advantage to heating treatment etc. In this case we could only make a determination on a certain product seasoning + color for a clearer acceptability of additives. Tastes can be analyzed separately, because they are more subjective (by area).

Therefore, in order to obtain qualitative and economic performance, in product processing must take into account both technical and functional considerations, nutrition and the economic ones.

\section{REFERENCES}

1. Banu, C. et al., (1997), Procesarea industrială a cărnii, Editura. Tehnică, Bucureşti, 351-364

2. Sălăgean, C. D., (2006) Researches concerning the optimization of using protein derivates in the processing of meat products in casings and the quality of the obtained products, PhD Thesis, USAMV Cluj-Napoca, 1-296 